\title{
A Logical Process for Labeling Food
}

\author{
A Alan Moghissi ${ }^{1,2 *}$, Richard Calderone ${ }^{1}$, Lisa Jaeger ${ }^{1,3}$, Dennis K McBride ${ }^{1,2}$ and Tomoko Steen ${ }^{1}$ \\ ${ }^{1}$ Georgetown University School of Medicine, USA \\ ${ }^{2}$ Institute for Regulatory Science, USA \\ ${ }^{3}$ Bracewell LLP, USA
}

Submission: December 23, 2017; Published: January 17, 2018

"Corresponding author: A Alan Moghissi, Georgetown University School of Medicine, USA, Email: moghissi@nars.org

Keywords: Regulatory science; Agricultural production; Pesticides

Abbreviations: MERSC: Metrics for Evaluation of Regulatory Science Claims; GE: Genetically-Engineered; GMO: Genetically Modified Organisms; FDA: Food and Drug Administration

\section{Introduction}

Preparation of this commentary was stimulated by several events including communication with the editorial staff of this journal and several publications resulting from the interaction among professors and students within a new program addressing regulatory science and other science for policy subjects at Georgetown University. This commentary relies heavily upon a paper Moghissi et al. [1] attempting to provide Metrics for Evaluation of Regulatory Science Claims (MERSC) based on Best Available Regulatory Science (BARS), a paper on golden rice Moghissi et al. [2], one on organic food [1], and one on food labeling [1].

Historically the evolution of growing food has occurred in three phases. The oldest and first phase consisted of identification and utilization of most efficient plants. The second phase was when cross breeding was developed and used with the objective of improving agricultural production. The third and current phase is the result of scientific advancement by applying available technologies to produce genetically modified organisms (GMO) and applying this technology to produce genetically-engineered (GE) food.

In recent years certain advocacy and other organizations have expressed a concern that organic food should be based on production processes that avoid the application of pesticides and manufactured fertilizers.

In the United States, the Food and Drug Administration (FDA) regulates food safety, the Department of Agriculture
(USDA) regulates operational aspects of food production, and the Environmental protection Agency (EPA) regulates the application of pesticides. Therefore, food produced within the regulatory domains of any one of the three jurisdictions must comply with the requirements of the respective agencies. It is important to note that all three agencies are legally required to use reliable science in their decisions [3].

In contrast to the science-based safety assessment of food, there are many food items whose quantity and quality are based on beliefs, desires of consumers. Whereas, certain segments of global population rely upon kosher food, another segments desire to consume halal food. Similarly, a significant number of humans prefer or are limited largely to vegetarian diets. Whereas the safety of such foods is evaluated by relevant regulatory agencies, the unique composition and production processes are determined by the realities of agricultural economics.

\section{Food Labeling Requirements}

We have argued Moghissi et al. [4] that food regulation should be based on several key factors:

\section{Communicating the content of food label}

By far the most important concern is accuracy and completeness of information included in food label. The consumers must be provided with the scientific foundations of applicable regulations in language and vocabulary that are understandable to the consumers. 


\section{Science based decision process}

Food safety, composition, and other scientifically-based concerns are ordinarily determined by regulatory agencies. Food labels intended for public consumption should include information that is identified by regulators.

\section{Belief-based issues}

Foods that are produced and marketed based on belief and desire of a segment of population should include objective information that is relevant to that segment of consumers.

\section{Mixing science and belief}

Labeling of food intended for public consumption may not include items that are based on the desire or belief of a segment of consumers. The food producers that mix science and belief are doing a disservice to consumers.

\section{The Jeffersonian Principle}

Public communication, as related to regulatory science, is traceable to Thomas Jefferson, the third president of the United States who stated that:

I know no safe depository of the ultimate power of the society but the people themselves; and if we think them not enlightened enough to exercise their control with a wholesome discretion, the remedy is not to take it away from them but to inform their discretion by education.

Based on the Jeffersonian Principle, consumers can be categorized in three groups.

\section{Group I: Scientific specialists}

This group consists of individuals who have relevant scientific education and experience in a scientific area that is being considered.

\section{Group II: Knowledgeable non-specialists}

This group includes those with general education who are not necessarily knowledgeable in the areas that are being addressed. Many government and industrial leaders and policy makers are included in this group.

\section{Group III: General public}

This group have either no or insufficient general knowledge about food products under consideration. However, it is assumed that this group is none-the-less capable of using information that is logical and explains science in a common language and vocabulary.

In all three cases above, the scientific basis of food safety communication (labels, primarily) should be written in language that knowledgeable non-specialists, and ideally the general public can follow.

\section{Organic food}

Unfortunate mixture of science-based and belief-based claims is evident in the marketing/labeling of organic food products. Some proponents of organic food claim that the inclusion of pesticides and manufactured fertilizers in food convey unnecessary toxicity. Whereas regulatory toxicology is a well-established applied discipline that is by all evidence capable of addressing uncertainties in science, hat what is being overlooked in such claims is the potential contamination of organic food with microorganisms-specifically when appropriate toxicology controls (e.g., application of pesticides) are not included in the agricultural chain. A report jointly produced by the Centers for Disease Control and Prevention, Food and Drug Administration, and the U.S. Department of Agriculture (2017) indicates that yearly nine million individuals become ill, over 50,000 are hospitalized, and as many as 1,300 die each year due to consuming food contaminated with pathogens. This report did not identify the contribution of organic food to the identified contaminants. However, as described by Moghissi et al. [5] organic crops rely primarily upon the application of treated manure as a source of fertilizer. For reasons reviewed elsewhere Moghissi et al. [2] agricultural products that are grown and cultivated using manure are more likely to contain pathogens than crops that rely upon toxically-regulated, manufactured fertilizers. Our argument is that those who believe that organic food is desirable are in their rights to prefer such, just as do those who consume kosher, halal, vegetarian or any other food based on their belief. The issue of importance is that there is a compelling need that such food be marketed (labeled) based on best available science, that is clearly understandable by consumers.

\section{Genetically engineered food}

The advancement of science and technology led to the evolution of GE agricultural products. As reviewed by Moghissi et al. [1] the Food and Drug Administration evaluates the safety of GE food with the same technical rigor that cross-bred food is evaluated. More practically, belief-based opposition to GE food often conveys significant adverse economic and human health consequences. The progression of GMO technologies has resulted in significant reductions in reliance upon synthetic fertilizers and pesticides-in the process, improving many of the important nutritional qualities of such GMO crops. The example of golden rice may be used to demonstrate the point: Scientifically unsupported, belief-based arguments are not sufficient nor even appropriate to compel regulatory opposition to golden rice that is known otherwise to provide vitamin A to communities that historically suffer from vitamin A deficiency - the nutritional deficiency associated with significant visual disorders such as nyctalopia (night blindness) and keratomalacia (the progressive buildup of opaqueness of the cornea, one of the most prevalent causes of blindness worldwide [6]. 


\section{Conclusion}

The scientific community is ethically obligated to provide society with objective scientific information that excludes ideology, belief, and expressed or implied politics. Societal objectives should remain separate from the purview of regulatory science. In the case of food safety, specifically, the Jeffersonian Principle as outlined above should prevail: Consumers should be confident that food marketing, and specifically product labeling, are based fundamentally on a thorough independence of belief and scientific inference.

\section{References}

1. Moghissi AA, Calderone RA, McBride DK, Jaeger L (2017) Innovation in regulatory science: Metrics for evaluation of regulatory science claims based on best available regulatory science. Journal of Regulatory Science 5(1): 50-59.
2. Moghissi AA, McBride DK, Garcia PM, Chen CW, Da S (2015) Assessment of organic versus conventional food using best available science concept and metrics derived from it. Technology and Innovation 17(3): 135-143.

3. CDC, FDA, and USD Foodborne illness attribution estimates for 2013 for Salmonella, Escherichia Coli 0157, Listeria Monocytogenes, and Campylobacter using multi-year outbreak surveillance data, United States.

4. Moghissi AA, Jaeger LM, Shafei D, Bloom LL (2017) Regulatory science requirements of labeling genetically modified food. Crit Rev Biotechnol 17: 1-8.

5. Moghissi AA, Pei S, Liu Y (2015) Golden rice: scientific and public information processes of a genetically modified organism. Crit Rev Biotechnol 36(3): 535-541.

6. Schwartz R (2017) Dermatologic manifestations of Vitamin A deficiency. Medscape.

Your next submission with Juniper Publishers
will reach you the below assets
- Quality Editorial service
- Swift Peer Review
- Reprints availability
- E-prints Service
- Manuscript Podcast for convenient understanding
- Global attainment for your research
- Manuscript accessibility in different formats
( Pdf, E-pub, Full Text, Audio)
- Unceasing customer service
Track the below URL for one-step submission
https://juniperpublishers.com/online-submission.php

